\title{
NILAI NUTRIENT DAN PERSEN AKG FOOD BARS BERBAHAN TEPUNG GARUT DAN PISANG
}

\author{
Choiriyah, Nurul Azizah ${ }^{1}$, Irra Chrisyanti Dewi ${ }^{1}$, Sonia Anggun Sanjaya ${ }^{1}$ \\ ${ }^{1}$ Seni Kuliner, Akademi Kuliner dan Patiseri OTTIMMO Internasional, Jalan Telaga Golf TC 4 No 2-3, Surabaya, \\ 60217, Indonesia
}

Email : nurul.azizah.choiriyah@gmail.com

\begin{abstract}
Abstrak
Tujuan penelitian untuk mengetahui efek perbandingan tepung garut dan buah pisang kepok terhadap nilai nutrient dan Angka Kecukupan Gizi (AKG) food bars. Perlakuan yang digunakan dalam pembuatan food bars yaitu tepung garut:pisang= 50:125 g (S1), perlakuan tepung garut:pisang= 75:100 g (S2) dan perlakuan tepung garut:pisang= 100:75 $\mathrm{g}$ (S3). Proses pembuatan food bars dilakukan dengan pencampuran margarin, gula dan garam hingga terbentuk foam, kemudian penambahan tepung garut, tepung terigu dan puree pisang kepok. Selanjutnya, pengulenan adonan, pencetakan dan pemanggangan $180^{\circ} \mathrm{C}$ dengan waktu 30 menit. Parameter yang dianalisis yaitu nilai nutrient dan persen Angka Kecukupan Gizi (AKG). Desain penelitian adalah Rancangan Acak Lengkap, analisis data menggunakan ANOVA one way dengan uji lanjut DMRT $\alpha<0,05$. Kadar air yang dihasilkan sebesar 9,66 \%- 11,09\%. Kadar protein ketiga food bars sekitar 6,32-6,58 \%. Kadar karbohidrat ketiga food bars sebesar 61,84\%-64,56\%. Kadar lemak produk antara 10,23-10,76 \%. Nilai energi produk food bars yang dihasilkan antara 363,29 kcal/100 g-373,59 kcal/100 g. Takaran saji produk food bars per sajian adalah 60 gram. sampel S1, S2, S3 masing-masing dapat memenuhi kebutuhan energi harian sebesar 10,42; 10,14 dan 10,33\% per sajian. Food bars S1, S2 dan S3 dapat memenuhi kebutuhan protein harian masingmasing sebesar 6,33; 6,33 dan 6,67\% per sajian. Food bars S1, S2 dan S3 dapat memenuhi kebutuhan karbohidrat harian sebesar 11,92; 11,42 dan 11,82 \% per sajian. Food bars S1, S2 dan S3 dapat memenuhi kebutuhan lemak harian sebesar 8,$96 ; 9,70$ dan $9,42 \%$ per sajian.
\end{abstract}

Keywords: Pisang Kepok, Tepung Garut, Food Bars, Angka Kecukupan Gizi

\begin{abstract}
The objective of this research was to evaluate the effect of comparison of arrowroot flour:kepok banana to nutrition value and percent daily value of food bars. The variables of the food bars manufactured were arrowroot flour:kepok banana $=$ 50:125 g (S1), arrowroot flour:kepok banana $=75: 100 \mathrm{~g}(\mathrm{~S} 2)$ and arrowroot flour:kepok banana $=100: 75 \mathrm{~g}(\mathrm{~S} 3)$. Preparation of food bars was done by mixing margarine, salt and sugar until foam formed, then adding arrowroot flour, wheat flour and banana puree. Then mixing until homogenous, molding and baking $180^{\circ} \mathrm{C}$ for $30 \mathrm{~min}$. The parameters were nutrition value and percent daily value. Research design using completely randomized design. Data analysis using ANOVA one way and DMRT $\alpha<0,05$. The moisture content of the products were 9,66\%-11,09\%. The protein content of the products were 6,32-6,58 \%. The carbohydrate content of the products were 61,84 \%-64,56\%. The fat content of the products between 10,23-10,76\%. Calory value of the products between $363,29 \mathrm{kcal} / 100 \mathrm{~g}-373,59 \mathrm{kcal} / 100 \mathrm{~g}$. The serving of the food bars was $60 \mathrm{~g}$. Percent daily value for protein of S1, S2, S3 were 10,42; 10,14 dan 10,33\% per serving. Percent daily value for fat of S1, S2, S3 were 8,96; 9,70 dan 9,42\% per serving. Percent daily value for carbohydrate of S1, S2, S3 were 11,92; 11,42 dan 11,82\% per serving.
\end{abstract}

\section{Pendahuluan}

Food bars merupakan produk bakery yang sudah popular di Indonesia dan biasanya terbuat dari bahan sumber karbohidrat, protein dan lemak. Menurut (Mahloko et al., 2019) penerimaan produk bakery dipengaruhi oleh pemilihan jenis tepung yang digunakan, proses pembuatan seperti pencampuran, aerasi, pemanggangan dan pendinginan.

Produk food bars tahan terhadap tekanan dibandingkan produk biskuit karena memiliki kadar air yang lebih tinggi. Olahan bakery biasanya terbuat dari tepung terigu karena mengandung gluten sehingga menghasilkan pengembangan adonan (Choiriyah et al., 2020). Produk food bars berbahan dasar tepung kedelai dan pisang telah dibuat oleh (Rahman et al., 2018) dan mendapat penilaian suka oleh panelis melalui uji hedonik. Tepung terigu dan tepung kedelai merupakan bahan impor sehingga diperlukan bahan pengganti lain sebagai ketahanan pangan bangsa Indonesia. Bahan baku lokal berpotensi dalam pembuatan food bars. 
Tabel 1 Kandungan nutrient food bars

\begin{tabular}{lllllll}
\hline Sampel & $\begin{array}{l}\text { Air } \\
(\%)\end{array}$ & $\begin{array}{l}\text { Abu } \\
(\%)\end{array}$ & $\begin{array}{l}\text { Protein } \\
(\%)\end{array}$ & $\begin{array}{l}\text { Lemak } \\
(\%)\end{array}$ & $\begin{array}{l}\text { Karbohidrat } \\
(\%)\end{array}$ & $\begin{array}{l}\text { Energy } \\
(\mathrm{kcal} / 100 \mathrm{~g})\end{array}$ \\
\hline S1 & $9,66 \mathrm{a}$ & $1,86 \mathrm{c}$ & $6,32 \mathrm{a}$ & $10,23 \mathrm{a}$ & $64,56 \mathrm{a}$ & $373,59 \mathrm{~b}$ \\
S2 & $11,09 \mathrm{a}$ & $1,41 \mathrm{a}$ & $6,34 \mathrm{a}$ & $10,76 \mathrm{a}$ & $61,84 \mathrm{a}$ & $363,29 \mathrm{a}$ \\
S3 & $9,75 \mathrm{a}$ & $1,67 \mathrm{~b}$ & $6,58 \mathrm{~b}$ & $10,51 \mathrm{a}$ & $63,97 \mathrm{a}$ & $369,41 \mathrm{ab}$ \\
\hline
\end{tabular}

Angka-angka yang diikuti oleh huruf yang berbeda menunjukkan beda nyata berdasarkan uji DMRT taraf kepercayaan $95 \%$.

Umbi garut merupakan bahan kaya akan karbohidrat. Olahan umbi garut menjadi tepung garut sudah tersedia secara komersil. Penelitian (Irmawati et al., 2018) menunjukkan tepung garut dapat dijadikan sebagai olahan biskuit dengan penerimaan konsumen yang baik dan memenuhi standar SNI. Hal ini berarti bahwa tepung garut juga berpotensi untuk dijadikan olahan food bars. Penelitian ini bertujuan untuk mengetahui efek perbandingan tepung garut dan buah pisang kepok terhadap nilai nutrient dan Angka Kecukupan Gizi (AKG).

\section{Bahan dan Metode Penelitian a. Bahan}

Komposisi bahan dari food bars pada penelitian ini yaitu: tepung terigu "Cakra Kembar", tepung garut "IELS Organic", buah pisang kepok, margarin "blue band", gula pasir "gulaku" dan garam. Bahan kimia yang digunakan untuk analisis terdiri dari $\mathrm{H}_{2} \mathrm{SO}_{4}, \mathrm{NaOH}$, $\mathrm{K}_{2} \mathrm{SO} 4, \mathrm{H}_{3} \mathrm{BO}_{3}, \mathrm{HCl}$, alkohol $96 \%$, n-heksan, dan aquadest.

\section{b. Alat}

Alat yang digunakan dalam pembuatan biskuit yaitu baskom plastik, mixer, rolling pin, sendok, sarung tangan plastik, telenan besar, chopper, oven, nampan dan lain-lain.

\section{c. Pembuatan Biskuit}

Proses pembuatan food bars mengacu pada metode (Ekafitri et al., 2013). Proses pembuatan food bars berbahan dasar tepung garut dan buah pisang sebagai berikut pencampuran bahan kering seperti gula sebanyak $80 \mathrm{~g}$ dan garam $1 \mathrm{~g}$, kemudian dilakukan penambahan 62,5 g margarin dan dilakukan pengadukan menggunakan mixer dengan waktu 20 menit hingga terbentuk foam. Selanjutnya, hasil campuran tersebut dilakukan penambahan tepung garut sesuai perlakuan yaitu 50,75 dan $100 \mathrm{~g}$ serta 125 gram tepung terigu. Selanjutnya dilakukan penambahan puree pisang kepok sebanyak 125, 100 dan $75 \mathrm{~g}$ (sesuai perlakuan). Pengulenan adonan dilakukan agar adonan menjadi kalis. Selanjutnya dilakukan pencetakan adonan dan pemanggangan pada oven dengan suhu $180^{\circ} \mathrm{C}$ dengan waktu 30 menit. Produk jadi untuk perlakuan tepung garut:pisang $=50: 125 \mathrm{~g}$ disebut $\mathrm{S} 1$, perlakuan tepung garut:pisang $=75: 100 \mathrm{~g}$ disebut $\mathrm{S} 2$ dan perlakuan tepung garut:pisang=100:75 g disebut $\mathrm{S} 3$.

\section{d. Pengamatan}

Analisis yang dilakukan pada produk biskuit yaitu analisis kadar air, analisis protein, analisis lemak, analisis karbohidrat, analisis total energi dan analisis persen Angka Kecukupan Gizi (\% AKG). Analisis kadar air menggunakan prinsip thermogravimetri. Kadar protein menggunakan prinsip metode kjeldahl. Analisis kadar lemak menggunakan metode soxhlet. Analisis karbohidrat menggunakan by difference (AOAC, 2005). Analisis persen AKG menggunakan perhitungan berdasarkan analisis nutrient dan Acuan Label Gizi (ALG)

e. Analisis Statistik

Penelitian ini menggunakan Rancangan Acak Lengkap dengan analisis statistic menggunakan program Anova one way dengan uji lanjut DMRT taraf kepercayaan 95\% untuk menguji beda nyata antar sampel.

\section{Hasil dan Pembahasan \\ a. Kandungan Nutrient Food Bars}

Nilai nutrient produk food bars ditunjukkan oleh Tabel 1. Penelitian (Katri Anandito et al., 2016) menghasilkan food bars dengan kadar air sebesar 16,45 $\%$. Pada penelitian ini, kadar air yang dihasilkan sebesar 9,66 \%- 11,09\%. Kadar air pada ketiga sampel tersebut tidak berbeda nyata. Kadar air pada penelitian ini lebih rendah daripada penelitian sebelumnya oleh (Agbaje et al., 2016), (Katri Anandito et al., 2016) dan (Santos et al., 2011). (Agbaje et al., 2016) membuat granola bar dengan kadar air sebesar 11,35-18,73\%. (Katri Anandito et al., 2016) membuat food bars berbahan tepung millet putih dan tepung kacang merah dengan kadar air sekitar $16 \%$. (Santos et al., 2011) membuat food bars berbahan dasar buah nangka dengan kadar air sekitar $20 \%$. Hal ini menunjukkan bahwa penelitian ini menghasilkan kadar air yang lebih baik daripada penelitian sebelumnya. Produk dengan kadar air yang rendah memiliki keunggulan dalam aspek mikrobiologi yaitu dapat memiliki umur simpan yang lebih lama (de Morais et al., 2018).

Analisis kadar abu merupakan parameter untuk nilai mineral bahan pangan. Kadar abu produk food bars berkisar antara 1,41\%-1,86\%. Nilai tersebut berada pada kisaran penelitian sebelumnya. Berdasarkan (Agbaje et al., 2016), Kadar abu produk granola bar sebesar 0,97$1,88 \%$. Sampel S1 memiliki kadar abu paling tinggi dan berbeda nyata dengan sampel lainnya, diikuti dengan 
sampel S2 dan kadar abu terendah pada sampel S3. Hal tersebut menunjukkan bahwa sampel S1 memiliki kandungan mineral tertinggi. Sampel S1 merupakan sampel dengan penggunaan jumlah buah pisang tertinggi. Buah pisang mengandung mineral yang lebih tinggi dibandingkan dengan tepung garut. Tepung garut memiliki kadar abu sebesar $0,3 \%$ dan buah pisang kepok mengandung kadar abu sebesar 1,0 g (RI, 2018). Buah pisang merupakan sumber mineral potasium atau kalium. Potasium merupakan elektrolit bermuatan positif. Potasium memiliki efek kesehatan terhadap jantung (Dotto et al., 2019).

Kadar protein ketiga food bars sekitar 6,32-6,58 $\%$. Kadar protein pada penelitian ini tergolong rendah, hal ini dikarenakan tepung garut dan buah pisang bukan merupakan bahan sumber protein. Produk S3 memiliki nilai protein tertinggi dan berbeda nyata dengan sampel lainnya. Sampel S3 merupakan sampel yang dibuat dengan berat tepung garut tertinggi. Tepung garut memiliki kadar protein sebesar 4,87 \% (Irmawati et al., 2018) sedangkan buah pisang kepok mengandung protein hanya sebesar 1,78 \% (Hapsari \& Lestari, 2016). Kadar lemak food bars pada produk ini sekitar 10,23$10,76 \%$. Ketiga produk tersebut tidak berbeda nyata dari segi kandungan lemak karena menggunakan margarin dengan berat yang sama. Kandungan lemak food bars dipengaruhi oleh penggunaan margarin (Fathonah et al., 2017). Nilai kandungan lemak pada penelitian ini tidak jauh berbeda dengan hasil penelitian (Agbaje et al., 2016) yang menghasilkan granola bar dengan kadar lemak sebesar 7,31-10,72\%.

Kadar karbohidrat ketiga food bars sebesar $61,84 \%-64,56 \%$. Ketiga produk tersebut tidak berbeda nyata pada kandungan karbohidratnya. Tepung garut dan buah pisang merupakan bahan yang kaya akan zat gizi karbohidrat (Irmawati et al., 2018), (Hapsari \& Lestari, 2016). Tepung garut dan pisang mengandung jenis karbohidrat tidak tercerna . Menurut (Dotto et al., 2019), buah pisang merupakan sumber pati resisten. Tepung garut mengandung tinggi serat (Gutiérrez et al., 2017). Bahan yang mengandung tinggi serat dan pati resisten dapat mencegah risiko obesitas karena memiliki daya cerna rendah (Patel, 2015).

Nilai energi produk food bars yang dihasilkan antara 363,29 kcal/100 g-373,59 kcal/100 g. Nilai energi food bars dipengaruhi oleh kadar karbohidrat, lemak dan protein. Komponen zat nutrient mayor food bars pada penelitian ini adalah karbohidrat dan lemak. Karbohidrat sampel S1 lebih tinggi dan berbeda nyata dengan sampel S2. Hal ini dikarenakan angka karbohidrat sampel S1 lebih besar daripada sampel S2.

\section{b. Angka Kecukupan Gizi Produk}

Produk food bars komersil biasanya disajikan sebesar 60 gram per sajian. Nilai Angka Kecukupan Gizi (AKG) produk food bars dihitung berdasarkan data hasil analisis nutrient dan Acuan Label Gizi (ALG) untuk usia dan kondisi umum (BPOM RI, 2016). Tabel 2 menunjukkan nilai $\mathrm{AKG}$.

Tabel 2 Nilai Angka Kecukupan Gizi Produk Food Bars

\begin{tabular}{lllll}
\hline No & Sampel & Nutrient & $\begin{array}{l}\text { Jumlah nilai gizi food bars } \\
\text { per 60 gram }\end{array}$ & \% AKG per sajian \\
\hline 1 & S1 & Energi (kkal) & 224 & 10,42 \\
& & Protein (g) & 3,8 & 6,33 \\
& & Karbohidrat (g) & 38,74 & 11,92 \\
& & Lemak (g) & $6 \mathrm{~g}$ & 8,96 \\
\hline 2 & S2 & Energi (kkal) & 218 & 10,14 \\
& & Protein (g) & 3,8 & 6,33 \\
& & Karbohidrat (g) & 37,1 & 11,42 \\
& & Lemak (g) & 6,5 & 9,70 \\
\hline 3 & S3 & Energi (kkal) & 222 & 10,33 \\
& & Protein (g) & 4 & 6,67 \\
& & Karbohidrat (g) & 38,4 & 11,82 \\
& & Lemak (g) & 6,31 & 9,42 \\
\hline
\end{tabular}

Berdasarkan Tabel 2 sampel S1, S2, S3 masingmasing dapat memenuhi kebutuhan energi harian sebesar 10,$42 ; 10,14$ dan $10,33 \%$ per sajian. Food bars S1, S2 dan S3 dapat memenuhi kebutuhan protein harian masing-masing sebesar 6,$33 ; 6,33$ dan $6,67 \%$ per sajian. Food bars S1, S2 dan S3 dapat memenuhi kebutuhan karbohidrat harian sebesar 11,92; 11,42 dan $11,82 \%$ per sajian. Food bars S1, S2 dan S3 dapat memenuhi kebutuhan lemak harian sebesar 8,96; 9,70 dan 9,42\% per sajian.

\section{Kesimpulan}

Kadar air yang dihasilkan sebesar 9,66\%- 11,09 $\%$ dan tidak ada perbedaan yang siginifikan antar sampel. Kadar protein ketiga food bars sekitar 6,32-6,58 \%, dimana S3 memiliki kadar protein tertinggi. Kadar karbohidrat ketiga food bars sebesar 61,84 \%-64,56\%. Tidak ada perbedaan yang nyata pada kandungan karbohidrat dan lemak antar sampel. Nilai energi produk food bars yang dihasilkan antara 363,29 kcal/100 g$373,59 \mathrm{kcal} / 100 \mathrm{~g}$. Takaran saji produk food bars per sajian adalah 60 gram. sampel S1, S2, S3 masing-masing dapat memenuhi kebutuhan energi harian sebesar 10,42; 
10,14 dan 10,33 \% per sajian. Food bars S1, S2 dan S3 dapat memenuhi kebutuhan protein harian masingmasing sebesar 6,$33 ; 6,33$ dan $6,67 \%$ per sajian. Food bars S1, S2 dan S3 dapat memenuhi kebutuhan karbohidrat harian sebesar 11,92; 11,42 dan $11,82 \%$ per sajian. Food bars S1, S2 dan S3 dapat memenuhi kebutuhan lemak harian sebesar 8,96; 9,70 dan 9,42\% per sajian.

\section{Daftar Pustaka}

1. Agbaje, R., Hassan, C. Z., Norlelawati, A., Abdul Rahman, A., \& Huda-Faujan, N. (2016). Development and physico-chemical analysis of granola formulated with puffed glutinous rice and selected dried Sunnah foods. International Food Research Journal, 23(2), 498-506.

2. AOAC. 2005. Official Method of Analysis.of Associated of Analytical Chemist. Washington DC.USA.

3. BPOM RI. (2016). Peraturan Kepala Badan Pengawas Obat dan Makanan Republik Indonesia Nomor 9 Tahun 2016 tentang Acuan Label Gizi. Badan Pengawasan Obat Dan Makanan Republik Indonesia, $1-28$. https://asrot.pom.go.id/img/Peraturan/Peraturan Kepala BPOM No. 9 Tahun 2016 tentang Acuan Label Gizi.pdf

4. Choiriyah, N. A., Dewi, I. C., \& Timur, J. (2020). SANTRIWATI PESANTREN X THE ACCEPTANCE OF WHITE BREAD FROM MOCAF FLOUR AND. 5(1), 44-49.

5. de Morais, M. P., Caliari, M., Nabeshima, E. H., Batista, J. E. R., Campos, M. R. H., \& Soares Júnior, M. S. (2018). Storage stability of sweet biscuit elaborated with recovered potato starch from effluent of fries industry. Food Science and Technology, 38(2), 216-222. https://doi.org/10.1590/fst.32916

6. Dotto, J., Matemu, A. O., \& Ndakidemi, P. A. (2019). Nutrient composition and selected physicochemical properties of fifteen Mchare cooking bananas: A study conducted in northern Tanzania. Scientific African, $6, \quad \mathrm{e} 00150$. https://doi.org/10.1016/j.sciaf.2019.e00150

7. Ekafitri, R., Sarifudin, A., \& Surahman, D. N. (2013). Pengaruh Penggunaan Tepung Dan Puree Pisang Terhadap Karakteristik Mutu Makanan Padat Berbasis-Pisang (Effect of Banana Flour and Puree on the Quality Characteristic of Banana-Based Snack Bar ). Gizi Dan Makanan, 36(2), 127-134.

8. Fathonah, S., Rosidah, R., \& Septianarta, S. (2017). Yellow Corn Biscuits for Early Childhood: High Energy and Beta-Carotene. Jurnal Bahan Alam Terbarukan, 7(1), 77-82. https://doi.org/10.15294/jbat.v7i1.9723

9. Gutiérrez, T. J., Herniou-julien, C., Álvarez, K., \& Alvarez, V. A. (2017). Structural properties and in vitro digestibility of edible and $\mathrm{pH}$-sensitive films made from guinea arrowroot starch and wastes from wine manufacture. Carbohydrate Polymers. https://doi.org/10.1016/j.carbpol.2017.12.039

10. Hapsari, L., \& Lestari, D. A. (2016). Fruit characteristic and nutrient values of four Indonesian banana cultivars (Musa spp.) at different genomic groups. Agrivita, 38(3), 303-311. https://doi.org/10.17503/agrivita.v38i3.696

11. Irmawati, Ansharullah, \& Baco, A. R. (2018). Pengaruh Formulasi Roti Tawar Berbasis Mocaf Dan Ubi Jalar Ungu (Ipomoea batatas L.) terhadap Nilai Proksimat dan Aktivitas Antioksidan. J. Sains Dan Teknologi Pangan, 3(2), 1163-1175.

12. Katri Anandito, R. B., Siswanti, S., Nurhartadi, E., \& Hapsari, R. (2016). FORMULASI PANGAN DARURAT BERBENTUK FOOD BARS BERBASIS TEPUNG MILLET PUTIH (Panicum milliaceum L.) DAN TEPUNG KACANG MERAH (Phaseolus vulgaris L.). Jurnal Agritech, 36(01), 23. https://doi.org/10.22146/agritech.10680

13. Mahloko, L. M., Silungwe, H., Mashau, M. E., \& Kgatla, T. E. (2019). Bioactive compounds, antioxidant activity and physical characteristics of wheat-prickly pear and banana biscuits. Heliyon, 5(10), $\mathrm{e} 02479$. https://doi.org/10.1016/j.heliyon.2019.e02479

14. Patel, S. (2015). Cereal bran fortified-functional foods for obesity and diabetes management: Triumphs, hurdles Seema Patel *. Journal of Functional Foods, 14, 255-269. https://doi.org/10.1016/j.jff.2015.02.010

15. Rahman, T., Luthfiyanti, R., Erwan, R. C., Andriansyah, Irwansyah, A. C., Nugroho, P., \& Choiriyah, N. A. (2018). The effect of temperature and time of baking to sensory quality of bananabased food bars Lembaga Ilmu Pengetahuan Indonesia. http://lipi.go.id/publikasi/the-effect-oftemperature-and-time-of-baking-to-sensory-qualityof-banana-based-food-bars/25307

16. RI, K. K. (2018). Data Komposisi Pangan Indonesia - Beranda. http://panganku.org/id-ID/view

17. Santos, C. T., Bonomo, R. F., Da Costa Ilhéu Fontan, R., Bonomo, P., Veloso, C. M., \& Fontan, G. C. R. (2011). Characterization and sensorial evaluation of cereal bars with jackfruit. Acta Scientiarum Technology, 33(1), 81-85. https://doi.org/10.4025/actascitechnol.v33i1.6425 